\title{
An assessment of the load-bearing capacity of the bolted connection of a steel roof girder
}

\author{
Jacek Nawrot ${ }^{1}$
}

\begin{abstract}
:
In this study, the non-preloaded bolted connection of a roof girder, commonly used in steel halls with a frame system, was analyzed. Two options were considered: a connection before reinforcement and one reinforced by adding a new row of bolts. For both of the analyzed variants, analytical calculations were performed based on the component method and numerical calculations using the Finite Element Method. The load capacity of the connection was checked before and after reinforcement. A large convergence of the calculation results for both methods was demonstrated. It was confirmed that the proposed reinforcement of the existing joint of the roof girder (by adding an new row of bolts) easily increases its load capacity (for the analyzed case, the load capacity of the connection increased by approx. $28 \%$ ). Such a reinforcement can be performed under load, with minimal interference to the existing joint, and the high deformability (elongation ability) of the bolts used allows for a full redistribution of internal forces in the reinforced joint.
\end{abstract}

\section{KEYWORDS:}

non-preloaded bolted connection; reinforcement of bolted connection; FEM

\section{Introduction}

Changing the use of existing steel halls or possible modernization works (replacement of the roofing, installation of devices on the roof, etc.) may lead to increased loads acting on a given facility. This often entails the need to strengthen its structure. Particular attention should be paid to ensuring the safety of the existing connections (welded or bolted) and, if necessary, strengthen them so that their load-bearing capacity - under increased load - is ensured.

In order to develop effective methods of connecting elements of steel structures, numerous experimental studies and numerical analyzes have been carried out [1-3]. In [4], the authors have presented a review of experimental studies on injection bolt joints, which can be an alternative to welded or riveted joints in reinforced structures of old steel bridges. Detailed experimental tests carried out in order to determine the strength of injection bolts under fatigue load are presented in [5]. It has been shown that the use of injections has a positive effect on the reduction of the spread of data related to fatigue strength, and the usefulness of this solution for reinforcing joints in old steel bridges has been confirmed. In [6], a numerical model was proposed that reflects the behavior of the beam-column screw connection, reinforced with retaining plates. It has been shown that the load-bearing capacity of the T-stub, which is the main component of the joint, increases with the increase of the thickness of the thrust plate, and the analyzed numerical model is consistent with the available results of experimental tests. In the work [7] an analysis of the bolt overlapping beam-column connection was carried out.

It has been shown that the support seat, in the form of an angle bracket, allows an increase in the number of bolts fixing the beam to the column without changing the geometry of the web contact, which leads to a reduction in the tension of the bolts fixed to the beam web and to 
a reduction in the size of the zone of maximum stresses occurring in the area of the web. Strengthening of bending bolted joints can be obtained by increasing the load capacity of the bolts in the tension zone by increasing the bolt class, diameter or number. When increasing the number of bolts in contact, check that the bolts have sufficient ability to extend. Otherwise the most stressed bolts may break before the joint reaches the designed load capacity. The ability to deform and redistribute internal forces can be taken into account in non-preloaded joints where bolts of a class lower than 8.8 are used [8].

\section{Goal and scope of work}

The goal of the work was to analyze the load capacity of a bolted connection of a roof girder (commonly used in steel halls within a frame system), which was reinforced by increasing the number of bolts in the tension zone of the joint.

The subject of the analysis is an non-preloaded bolted connection made with M24 class 5.6 bolts in two options: before reinforcement - option 1 (Fig. 1) and after reinforcement by adding one row of bolts - option 2 (Fig. 2). It was assumed that due to the increased load on the roof of the hall, the value of the bending moment acting in the place of the joint would be $170 \mathrm{kNm}$.

Other connection parameters used in the calculations were:

- roof girder - IPE 330

- welds connecting the web with the end plate - fillet welds, thickness $3.5 \mathrm{~mm}$

- welds connecting the flanges with the end plate - fillet, thickness $6 \mathrm{~mm}$

- end plate dimensions: $18 \times 180 \times 440$

- steel grade: S355
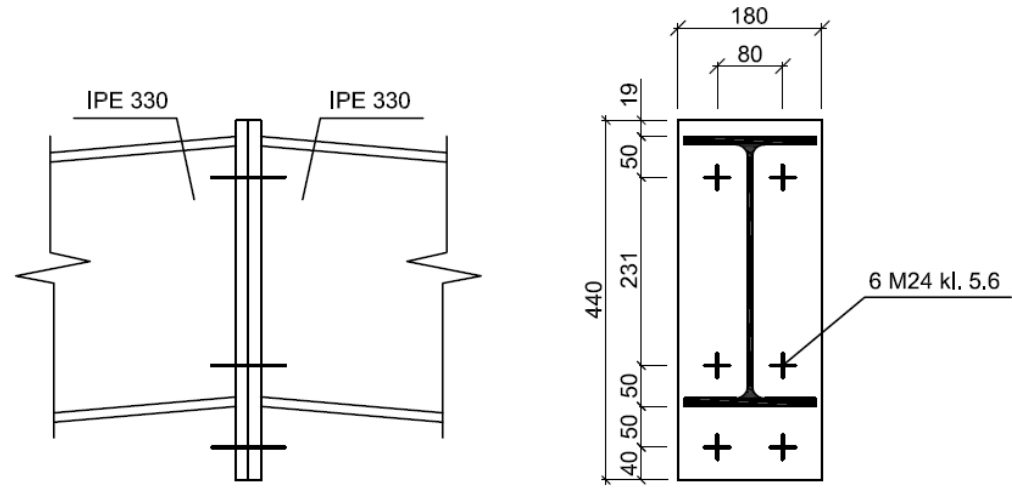

Fig. 1. The analyzed connection before reinforcement - option 1
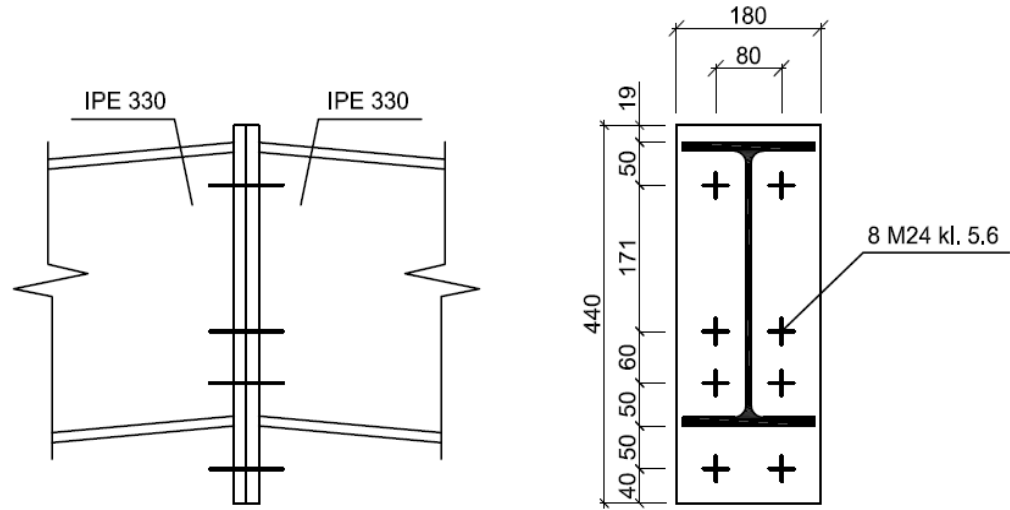

Fig. 2. The analyzed connection after reinforcement - option 2 


\section{Calculation results}

\subsection{Analytical calculations}

Analytical calculations were performed using the component method, in accordance with the guidelines contained in the standard [9]. The bending resistance of the analyzed node was determined and compared with the value of the bending moment at the connection point. The calculation results for both variants of the analyzed combination are presented in Table 1 .

Table 1

Results of analytical calculations

\begin{tabular}{|l|l|l|l|}
\hline $\begin{array}{l}\text { The considered } \\
\text { connection option }\end{array}$ & $\begin{array}{l}\text { Bending moment at the connection } \\
\text { point, med., kNm }\end{array}$ & $\begin{array}{l}\text { The load capacity of } \\
\text { the joint, } \mathrm{M}_{\mathrm{j} R \mathrm{R}}, \mathrm{kNm}\end{array}$ & $\begin{array}{l}\text { The load capacity } \\
\text { condition, } \mathrm{M}_{\mathrm{Ed}} / \mathrm{M}_{\mathrm{j} R \mathrm{R},} \%\end{array}$ \\
\hline Option 1 & 170,00 & 137,99 & 123,20 \\
\hline Option 2 & 170,00 & 176,80 & 96,15 \\
\hline
\end{tabular}

The load capacity of the joint before reinforcement is insufficient, the load capacity condition is exceeded by more than $23 \%$. After the joint is strengthened by adding a new series of bolts, the load capacity of the joint increases by over $28 \%$ and is greater than the bending moment acting on the joint.

\subsection{Numerical calculations}

Numerical calculations were performed using the IdeaStatica program based on the finite element method (FEM). The values of the reactions in the individual bolt rows, caused by the bending moment occurring at the joint and the stress distribution at the joint, are shown in Figures 3 (option 1) and 4 (option 2).

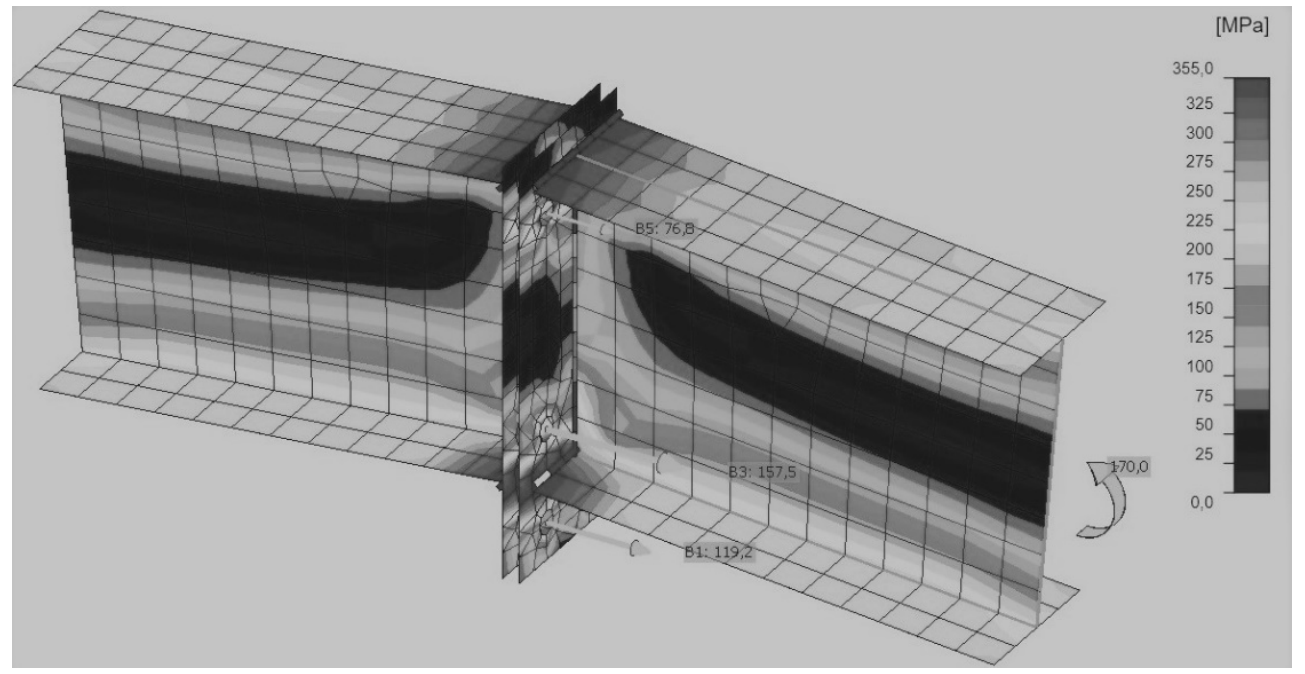

Fig. 3. Stress distribution and reactions in bolts - option 1

The reactions for the most stressed series of bolts were compared with their load capacity. The calculation results are presented in Table 2. 


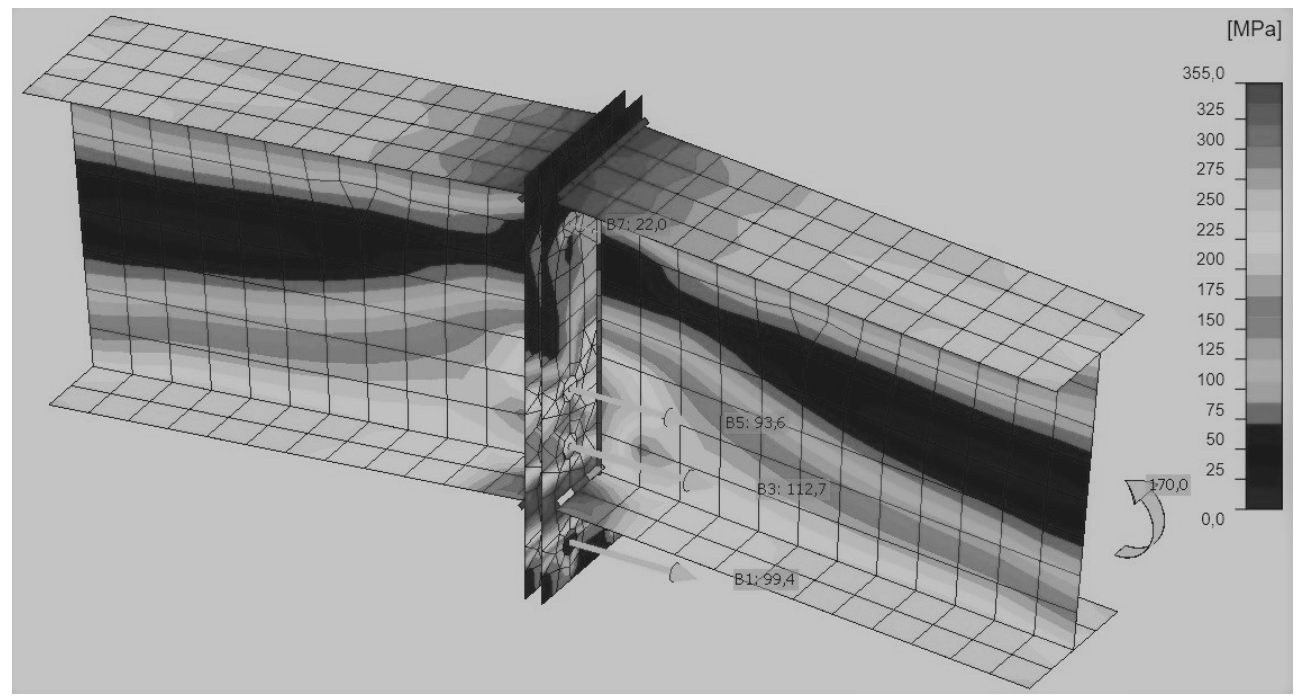

Fig. 4. Stress distribution and reactions in bolts - option 2

\section{Table 2}

Results of numerical calculations

\begin{tabular}{|l|l|l|l|}
\hline $\begin{array}{l}\text { The considered } \\
\text { connection option }\end{array}$ & $\begin{array}{l}\text { Reaction in the most strenuous } \\
\text { bolt series, } \mathrm{F}_{\mathrm{t}, \mathrm{Ed}}, \mathrm{kN}\end{array}$ & $\begin{array}{l}\text { Bolt load capacity } \mathrm{F}_{\mathrm{t}, \mathrm{Rd}} \\
\mathrm{kN}\end{array}$ & $\begin{array}{l}\text { The load capacity } \\
\text { condition } \mathrm{F}_{\mathrm{t}, \mathrm{Ed}} / \mathrm{F}_{\mathrm{t}, \mathrm{Rd}}, \%\end{array}$ \\
\hline Option 1 & 157.50 & 127.10 & 123.92 \\
\hline Option 2 & 112.70 & 127.10 & 88.67 \\
\hline
\end{tabular}

The load capacity condition for the most stressed series of bolts in an unreinforced connection is exceeded by approx. $23 \%$. After the reinforcement is made, the load-bearing capacity of the connection is sufficient. The zones of maximum stresses occur at the point where the girder flanges meet the end plate (Figs. 3 and 4), however, in none of the considered options, did these stresses exceed the permissible value equal to the yield stress of steel. The load-bearing capacity of the welds connecting the end plate with the girder is also ensured in both cases.

\section{Conclusions}

The results of the analytical calculations carried out in accordance with [9] show a great convergence with the results of the numerical calculations made with the use of the IdeaStatica program. For a joint before reinforcement, the load capacity is exceeded by approx. $23 \%$ (for both analytical and numerical calculations), for a reinforced joint, the discrepancy of results is approx. $8.4 \%$ (the capacity range determined on the basis of analytical calculations is smaller than in the case of numerical calculations). The calculation algorithm according to [9] is based on the component method, where the load-bearing capacity of a node is determined by the load-bearing capacity of its individual components: bolts, parts of elements of joined sections, end plates. In numerical calculations, reactions in bolts from the load acting on the connection (bending moment $\mathrm{M}_{\mathrm{Ed}}$ ) are determined, which is compared with the bolt capacity. For the parts of the joined elements in the contact zone, the actual values of stresses and strains are determined and compared with the permissible values. The finite element method (FEM) allows for a more accurate modeling of the analyzed connection and gives more accurate results than the component method, containing some simplifications, developed on the basis of the mechanical model of the joint [10]. In the case of the analyzed connection, the estimation of the load 
capacity, based on the standard [9], gives more conservative results than those obtained from the numerical calculations, therefore its load capacity can be safely determined according to [9].

The proposed reinforcement of the existing butt joint of the roof girder (by adding a new series of bolts) makes it possible to easily increase its load-bearing capacity (for the analyzed case, the load-bearing capacity of the joint increased by approx. 28\%). Such reinforcement can be performed under load, with minimal interference in the existing joint, and the high deformability (ability to elongate) of the bolts used allows for full redistribution of internal forces in the reinforced joint.

The effectiveness of the discussed method of reinforcement depends on the height of the girder cross-section. The greater the distance of the additional bolt row from the flange of the rafter to be compressed (larger arm of internal forces), the greater the increase in the load capacity of the joint, provided that the load capacity of the remaining components of the joint, including the welds connecting the end plate with the girder, will be sufficient.

\section{References}

[1] Tahira M., Mohammadhosseinia H., Shek Poi Ngiana, Kori Effendi M., I-beam to square hollow column blind bolted moment connection:Experimental and numerical study, Journal of Constructional Steel Research 2018, 148, 383-398.

[2] Zhi-Bin Wang, Zhong Tao, De-Shan Li, Lin-Hai Han, Cyclic behaviour of novel blind bolted joints with different stiffening elements, Thin-Walled Structures 2016, 101, April, 157-168.

[3] Boudia S., Boumechra N., Bouchair A., Missoum A., Modeling of bolted endplate beam-to-column joints with various stiffeners, Journal of Constructional Steel Research 2020, 167, 105963, 1-10.

[4] Correia J., PedrosaB., Cordeiro Raposo P., Pinho De Jesus A., Gervásio H., Lesiuk G., Rebelo C., Calçada R., Proenca l.: Fatigue Strength Evaluation of Resin-Injected Bolted Connections Using Statistical Analysis, Engineering 2017, 3, 795-805.

[5] Pedrosa B., Correia J., Rebelo C., Veljkovic M., Gervasio H., Fatigue experimental characterization of preloaded injection bolts in a metallic bridge strengthening scenario, Engineering Structures 2021, 234, 112005, 1-10.

[6] Al-Khataba Z., Bouchair A., Analysis of a bolted T-stub strengthened by backing-plates with regard to Eurocode 3, Journal of Constructional Steel Research 2007, 63, 12, 1603-1615.

[7] Kasza P., Nawrot J., Analysis of the load-carrying capacity of a bolted connection between a steel floor beam and a column, Zeszyty Naukowe Politechniki Częstochowskiej 2020, seria Budownictwo nr 26, 76-82.

[8] Bródka J., Kozłowski A. Ligocki I., Łaguna J., Ślęczka L., Projektowanie i obliczanie połączeń I węzłów konstrukcji stalowych, tom 2, Polskie Wydawnictwo Techniczne 2015.

[9] PN-EN 1993-1-8 Eurokod 3: Projektowanie konstrukcji stalowych, Część 1-8: Projektowanie węzłów.

[10] Tschemmernegg F., Queiroz G., Mechanical Modeling of Semi-Rigid Joints for the Analysis of Framed Steel and Composite Structures. In: Connection in Steel Structures III: Behaviour, Strength and Design. Eds. R. Bjorhovde, A. Colson, R. Zandonini, Elsevier, London 1996.

\section{Ocena nośności połączenia śrubowego stalowego dźwigara dachowego}

\section{STRESZCZENIE:}

Poddano analizie niesprężone połączenie śrubowe rygla dachowego, wysteppujące powszechnie $\mathrm{w}$ halach stalowych o układzie ramy pełnościennej. Rozpatrzono dwa warianty: połączenie przed wzmocnieniem oraz po wykonaniu wzmocnienia poprzez dodatnie nowego szeregu śrub. Dla obu analizowanych wariantów wykonano obliczenia analityczne w oparciu o metodę składnikową oraz numeryczne wykorzystujące metodę elementów skończonych. Sprawdzono nośność połączenia przed i po wzmocnieniu. Wykazano duża zbieżność wyników obliczeń dla obu zastosowanych metod. Potwierdzono, iż zaproponowane wzmocnienie istniejącego połączenia doczołowego rygla dachowego (poprzez dodanie dodatkowego szeregu śrub) pozwala w prosty sposób zwiększyć jego nośność (dla analizowanego przypadku nośność połączenia wzrosła o ok. 28\%). Wzmocnienie takie można wykonać pod obciążeniem, przy minimalnej ingerencji w istniejący styk, a wysoka odkształcalność (zdolność do wydłużenia) zastosowanych śrub pozwala na pełną redystrybucje sił wewnętrznych we wzmocnionym połączeniu.

\section{SŁOWA KLUCZOWE:}

niesprężone połączenia śrubowe; wzmacnianie połączeń śrubowych; MES 